\title{
COFFEE SILVERSKIN AND EXPIRED COFFEE POWDER USED AS ORGANIC FERTILIZERS
}

\author{
Ruan Carnier ${ }^{1}$, Ronaldo Severiano Berton ${ }^{2}$, Aline Renee Coscione ${ }^{3}$, \\ Adriana Marlene Moreno Pires ${ }^{4}$ Jessica Zuanazzi Corbo ${ }^{5}$
}

(Received: September 17, 2018; accepted: January 21, 2019)

\begin{abstract}
The coffee industry produces a wide range of organic wastes, some in large amounts, and most of them do not have a well-defined final disposal. The agricultural use of these wastes can be based on the recycling of nitrogen $(\mathrm{N})$, but their chemical characterization and evaluation with soil under controlled conditions are required. The aim in this work was to evaluate the use of coffee silverskin and expired coffee powder as organic fertilizers. The wastes were chemically characterized according to CONAMA'S resolution No. 375 and passed through Brazil's Agriculture Ministry normative for organic fertilizers. A greenhouse experiment with Rhodic Ferralsol soil and maize as a model plant was carried out to obtain the agronomic efficiency index (AEI) for nitrogen. Three treatments were considered: one control (without waste), ammonium nitrate as a mineral reference, and both organic wastes, at a dose of $450 \mathrm{mg}$ of Kjeldahl nitrogen per pot, in triplicate. The characterization results were favorable to the wastes as nitrogen sources for agriculture. However, the AEIs obtained were low $(0.5$ and $7.9 \%$ for the expired coffee powder and the coffee silverskin, respectively) compared to that of the mineral reference $(92 \%)$. Although coffee silverskin and expired coffee powder showed nitrogen levels were well above the minimum require by normative $(0.5 \% \mathrm{~m} / \mathrm{m})$, its use as organic fertilizers (as exclusive sources of $\mathrm{N}$ ) is not recommended since less than $10 \%$ of $\mathrm{N}$ was available as showed by the AEI index.
\end{abstract}

Index terms: Agricultural use, chemical characterization, waste management.

\section{USO DA PELÍCULA E DO PÓ DE CAFÉ VENCIDO COMO FERTILIZANTES ORGÂNICOS}

RESUMO: A indústria de café produz uma série de resíduos, sendo alguns em grande quantidade, a maioria dos quais sem uma disposição final bem definida. O uso agrícola destes resíduos pode se basear na reciclagem do nitrogênio $(\mathrm{N})$, porém a caracterização química e a avaliação destes materiais em condições controladas no solo são obrigatórias. Portanto, o objetivo desse trabalho foi avaliar o uso agrícola da película de café e pó de café vencido como fertilizantes orgânicos. A caracterização química foi realizada segundo a resolução 375 do CONAMA e os resultados comparados com a legislação para fertilizantes do Ministério da Agricultura. Um experimento em casa de vegetação com amostras de um Latossolo Vermelho distrófico, utilizando o milho como planta teste, foi realizado para obtenção do Índice de Eficiência Agronômica (IEA) para nitrogênio. Três tratamentos foram utilizados: controle (sem resíduo), nitrato de amônio como referência mineral e os ambos os resíduos, na dose de $450 \mathrm{mg}$ de nitrogênio Kjeldahl por vaso, em triplicata. Os dados da caracterização química calcularam-se os desvios padrões. Os resultados de caracterização foram favoráveis ao uso agrícola desses resíduos como fonte de nitrogênio, porém os IEAs obtidos foram baixos ( 0.5 e $7.9 \%$ para o pó e película de café respectivamente) quando comparados com a referência mineral $(92 \%)$. Embora a película e o pó de café apresentem teores de nitrogênio acima do mínimo exigido pela instrução normativa $(0,5 \% \mathrm{~m} / \mathrm{m})$, o uso como fertilizantes orgânicos (como fonte exclusiva de $\mathrm{N}$ ) não é recomendada, visto que menos de $10 \%$ do $\mathrm{N}$ estava disponível como mostrado pelo IEA.

Termos para indexação: Uso agrícola, caracterização química, gerenciamento de resíduos.

\section{INTRODUCTION}

The presence of plant nutrients, mainly nitrogen, is associated with a high content of organic matter in many organic wastes. For this reason, its use as nitrogen source in agriculture are particularly interesting, as it can be both environmentally and economically valuable (PAULA et., 2013). Based on this relationship, organic fertilizers must have at least $0.5 \%(\mathrm{~m} / \mathrm{m})$ of total Nitrogen in its content, according to the Brazilian normative $\mathrm{N}^{\circ} 25$ from the Agriculture Ministry. Also, a minimum content of $15 \%(\mathrm{~m} / \mathrm{m})$ of carbon is required. If the minimum amount of $\mathrm{N}$ is not reached, organic wastes with potential use in agriculture might be registered as soil conditioners. For this use, only its carbon content and cation exchange capacity are regulated by the Brazilian normative No35 (BRASIL, 2006). The presence of any other mineral nutrient at material used as organic fertilizer requires minimum contents addressed also by Brazilian normative $\mathrm{N}^{\circ} 25$.

Brazil is the largest coffee producer, being responsible for $30.1 \%$ of coffee beans grown worldwide, and has a trade value of more than

\footnotetext{
1,2,35Instituto Agronômico - Avenida Barão de Itapura, 1.481 - Botafogo - 13.020-902 - Campinas - SP - rcarnier10@gmail.com, berton@iac.sp.gov.br, aline@iac.sp.gov.br, jezuanazzi@outlook.com

${ }^{4}$ Embrapa Meio Ambiente - Rodovia SP 340 - Km 127,5 - Tanquinho Velho -1 3.820-000 - Jaguariúna - SP - adriana.pires@embrapa.br
}

Coffee Science, Lavras, v. 14, n. 1, p. 24 - 32, jan./mar. 2019 
20.6 billion Brazilian reais (CONCEIÇÃO et al., 2017). However, within the coffee bean agricultural chain, approximately $50 \%$ of the volume of products generated are wastes, such as the coffee husks, pulp, parchment and coffee silverskin (MATIELLO, 1991; ESQUIVEL; JIMÉZEZ, 2012). Several of these wastes may be used in agriculture as fertilizers or soil conditioners if meet the normative requirements listed above. The reuse of coffee silverskin, the main waste product of the coffee-roasting industry, could be also a significant alternative to its environmental disposal (TOSCHI et al., 2014).

In contrast to mineral fertilization, the use of organic materials as fertilizers depends on organic matter mineralization for the plant's nutrient release (ECKHARDT et al, 2016). For this reason, nitrogen availability in the form of inorganic nitrogen is often lower than that in mineral fertilizers. These characteristics can protect the environment and meet the plant's needs. Organic matter mineralization is affected by several factors, such as $\mathrm{pH}, \mathrm{C} / \mathrm{N}$ ratio and water availability (PAULA et al., 2013). For this reason, only the presence of the minimum amounts of nitrogen, according to the Brazil's Agriculture Ministry normative cited earlier, in new fertilizers based on recycling of organic wastes may not be enough, and the evaluation of nitrogen availability in tests with soils by means of the agronomic efficiency index (AEI) is advisable.

In addition, besides to the agronomic efficiency index (AEI) testing for nitrogen, the chemical characterization of organic wastes that shall be used as new organic fertilizers is mandatory as a first step in its evaluation. The chemical characterization of organic wastes is the basis for the agronomic recommendation and is usually performed following the requirements described in the CONAMA'S resolution No. 375. The characterization of the wastes is important not only to identify the concentration of macro and micronutrients but also to indicate other attributes and relationships among attributes in the waste composition. Furthermore, it can also show the presence of heavy metals, that limits are regulated by the Brazilian normative instruction No7 (BRASIL, 2016). After the characterization, the data was compared with Brazil's Agriculture Ministry normative for organic fertilizers to verify if it is in accordance.

The aim of this work was to evaluate the use of coffee silverskin and expired coffee powder as organic fertilizers.

\section{MATERIAL AND METHODS}

Coffee silverskin and the expired coffee powder were obtained from a sewage sludge treatment plant where these materials are used for sewage sludge composting. The samples were air-dried, homogenized and sieved through 2-mm. All analyses were run in triplicate. Chemical characterization followed the standard established by the National Environment Council resolution No. 375 (CONAMA, 2006). Moisture was determined according to EPA-SW 846, with drying to constant weight at $65^{\circ} \mathrm{C}$. The $\mathrm{pH}$ was measured using $2 \mathrm{~g}$ of moist sample and $20 \mathrm{ml}$ of deionized water, and the mixture was stirred for $5 \mathrm{~min}$ at $220 \mathrm{rpm}$ and rested for $30 \mathrm{~min}$. For inorganic N, 5-g samples was distilled with 50 $\mathrm{ml}$ of $1.0 \mathrm{~mol} / \mathrm{L} \mathrm{KCl}, 0.2 \mathrm{~g}$ of $\mathrm{MgO}$, and $0.2 \mathrm{~g}$ of Devarda alloy. The distillate was collected in $5 \mathrm{~mL}$ of $20 \mathrm{~g} / \mathrm{L} \mathrm{H}_{3} \mathrm{BO}_{3}$ and titrated with 0.0025 $\mathrm{mol} / \mathrm{L} \mathrm{H}_{2} \mathrm{SO}_{4}$ (BREMNER, 1996). Nitrite and nitrate were determined according to Mulvaney (1996). For organic N (N-Kjeldahl), $0.05 \mathrm{~g}$ of oven-dried samples were mixed with $3 \mathrm{~mL}$ of concentrated $\mathrm{H}_{2} \mathrm{SO}_{4}$ and placed in a digester block $\left(360^{\circ} \mathrm{C}\right)$ for $3 \mathrm{~h}$; the sample was then distilled with $20 \mathrm{~mL}$ of $10 \mathrm{~mol} / \mathrm{L} \mathrm{NaOH}$. The distillate was also collected in $20 \mathrm{~mL}$ of $20 \mathrm{~g} / \mathrm{L} \mathrm{H}_{3} \mathrm{BO}_{3}$ and then titrated with $0.0025 \mathrm{~mol} / \mathrm{L} \mathrm{H}_{2} \mathrm{SO}_{4}$ (APHA, 2017). Total solids and volatile solids were obtained by drying samples at $105^{\circ} \mathrm{C}$ and then combusting at $550^{\circ} \mathrm{C}$ for $4 \mathrm{~h}$ (APHA, 2017). Organic carbon was determined by the $\mathrm{K}_{2} \mathrm{Cr}_{2} \mathrm{O}_{7}$ method (NELSON; SOMMERS, 1996). Ca, K, P, Mg, S, Cu, Fe, Ni, $\mathrm{Mn}, \mathrm{Mo}, \mathrm{Si}, \mathrm{Zn}, \mathrm{Al}, \mathrm{As}, \mathrm{Ba}, \mathrm{Cd}, \mathrm{Cr}, \mathrm{Pb}, \mathrm{Hg}$, and $\mathrm{Na}$ were extracted in a microwave oven (EPA, 2018). $\mathrm{K}$ and $\mathrm{Na}$ were quantified by flame photometry and the other elements by ICP-AES. The cation exchange capacity (CEC) was measured following the procedure described by Normative No. 17 (BRASIL, 2007). The electrical conductivity (EC) was measured in a 1:5 (10 g of waste: $50 \mathrm{~mL}$ of water) extract. From triplicate data, the average and standard deviation were calculated. The C:N ratio was obtained considering $\mathrm{N}-\mathrm{Kjeldahl}$ and organic $\mathrm{C}$.

The experiment was carried out in a greenhouse at the Agronomic Institute of Campinas, State of São Paulo, Brazil (2253'37.27' S; 47³'54" W), from December 2016 to February 2017. The soil sample, collected from the $0-20 \mathrm{~cm}$ depth of a Rhodic Ferralsol soil, was air-dried, homogenized and sieved through 2-mm. The soil characteristics are shown in Table 1 and were determined according to Raij et al. (2001). 
TABLE 1 - Soil fertility attributes.

\begin{tabular}{|c|c|c|c|c|c|c|c|c|}
\hline Soil Organic Matter & & $\mathrm{pH}$ & $\mathrm{H}+\mathrm{Al}$ & $\mathrm{Ca}$ & $\mathrm{Mg}$ & K & $\mathrm{BS}$ & $\mathrm{CEC}$ \\
\hline $\mathrm{g} \mathrm{dm}^{-3}$ & & - & \multicolumn{6}{|c|}{$\mathrm{mmol}_{\mathrm{c}} \mathrm{dm}^{-3}$} \\
\hline 27.0 & & 4.1 & 54.0 & 7.0 & 5.0 & 0.7 & 12.7 & 66.7 \\
\hline N Kjeldahl & $\mathrm{P}$ & $\mathrm{S}$ & $\mathrm{V}$ & $\mathrm{B}$ & $\mathrm{Cu}$ & $\mathrm{Fe}$ & $\mathrm{Mn}$ & $\mathrm{Zn}$ \\
\hline $\mathrm{g} \mathrm{kg}^{-1}$ & \multicolumn{2}{|c|}{$\mathrm{mg} \mathrm{dm}{ }^{-3}$} & $\%$ & \multicolumn{5}{|c|}{$\mathrm{mg} \mathrm{dm}^{-3} \longrightarrow$} \\
\hline 1.4 & 8.0 & 11.0 & 19.0 & 0.3 & 4.4 & 60.0 & 7.5 & 0.9 \\
\hline
\end{tabular}

$\mathrm{H}+\mathrm{Al}$ by SMP buffer. $\mathrm{Cu}, \mathrm{Fe}, \mathrm{Mn}$ and $\mathrm{Zn}$-DTPA pH 7.3. V-base saturation, B.S.-sum of basis; CEC- cation exchange capacity

The greenhouse experiment was performed using 2-kg pots vases with maize, as the test plant. Five plants were kept per vase. The treatments were control (without residue), ammonium nitrate as mineral reference, and both organic wastes, at a dose of $450 \mathrm{mg}$ of Kjeldahl nitrogen per pot. The corresponding experimental design was a completely randomized block design, with four treatments, in triplicate, with a total of 12 vases.

The pots were prepared as follows: 1- the soil base saturation was settled to $70 \%$ by the addition of $2.7 \mathrm{~g}$ of lime per pot, and the moisture was adjusted to $60 \%$ of soil water retention, with incubation for 10 days; 2 - to each pot, the calculated amount of waste or ammonium nitrate was added and incubated for 15 days; and 3- all pots were fertilized by the addition of $0.45,0.4$, $0.46,0.27$ and $0.17 \mathrm{~g}$ per pot of $\mathrm{K}, \mathrm{P}, \mathrm{Ca}, \mathrm{Mg}$ and $\mathrm{S}$, respectively, plus micronutrients $(2.0,1.0$, $0.28,1.0,6.3$ and $8.0 \mathrm{mg}$ per pot of $\mathrm{B}, \mathrm{Mn}, \mathrm{Mo}$, $\mathrm{Fe}, \mathrm{Zn}$ and $\mathrm{Cu}$, respectively). After fertilization, 10 healthy and homogeneous seeds of maize (AG8676PR02 variety) were sown uniformly distributed on the surface of each pot at a depth of $2 \mathrm{~cm}$. After emergence, five seedlings were kept per pot. Thirty-seven days after seeding, the shoots were measured and cut. Fresh weight was registered, followed by washing with water and oven drying until a constant weight at a $65^{\circ} \mathrm{C} \pm 5$ ${ }^{\circ} \mathrm{C}$. The dry matter was milled, and its $\mathrm{N}$ Kjeldahl determined (BREMNER, 1996).

Soil and plant data were submitted to ANOVA and Tukey's test for average comparison of treatments $(\mathrm{p} \leq 0.05)$. To perform these analyses, the statistical program used was the SISVAR ${ }^{\circledR}$ 5.6 version.

Shoot nitrogen extraction was calculated as follows (equation 1):

$$
\mathrm{SNE}=\frac{\mathrm{DM} \times \mathrm{N} \text { content }}{1000}
$$

Where: SNE is the shoot nitrogen extraction $\left(\mathrm{mg} \mathrm{pot}^{-1}\right)$;DM is dry matter $\left(\mathrm{g} \mathrm{pot}^{-1}\right) ; \mathrm{N}$ content is the nitrogen found in shoots $\left(\mathrm{g} \mathrm{kg}^{-1}\right)$. The agronomic efficiency index (AEI) was calculated as described by Farinelli e Lemos (2010) (equation 2):

$$
\text { AEI }(\%)=\frac{(\text { SNE1-SNE0 }) \times 100}{N \text { applied }}
$$

Where:

SNE0 is the shoot nitrogen extraction in the control; SNE1 is the shoot nitrogen extraction in the nitrogen sources (wastes or ammonium nitrate) and $\mathrm{N}$ applied that was $450 \mathrm{mg}$ of $\mathrm{N}$ per pot.

The relative agronomic efficiency index (RAEI) was calculated as follows (equation 3):

$$
\text { RAEI }(\%)=\frac{\text { organic waste AEI }}{\text { Ammonium nitrate AEI }} \times 100
$$

\section{RESULTS AND DISCUSSION}

The chemical characterization of the organic wastes is shown in Table 2. The moisture of both materials was quite low (1.2 and $16.6 \%$ $(\mathrm{m} / \mathrm{m})$ for expired coffee powder and coffee silverskin, respectively) and was consistent with the roasting of the beans to which the wastes were associated. The low moisture of such material is favorable when transport costs for its application are considered. The $\mathrm{pH}$ of coffee silverskin was 6.8, and that of expired coffee powder was 5.0. A soil $\mathrm{pH}$ in the range 6.0 to 7.0 is considered optimum for plant nutrient availability. Previous studies showed that application of high ratios of expired coffee powder could result in a soil $\mathrm{pH}$ below 6.0 (MELO et al., 2008). However, the final soil $\mathrm{pH}$ after organic amendment depends on several factors such as the rate of waste application, the waste reaction with the soil and the soil buffering capacity and organic matter content (RONQUIM, 2010). 


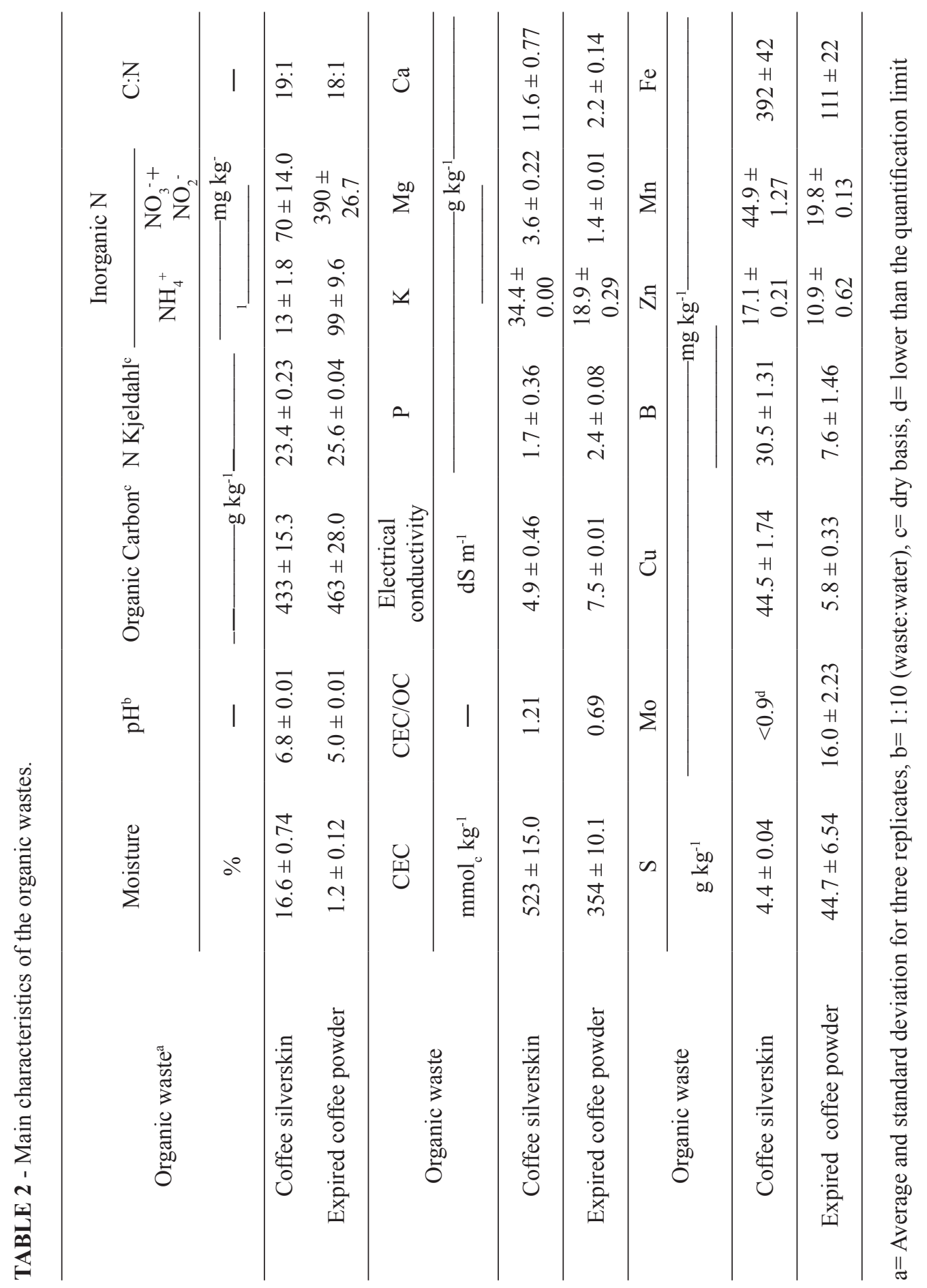


Both wastes presented similar concentrations of organic carbon (43\% to $46 \%$ of Organic Carbon) and organic nitrogen (2.3 to $2.6 \%$ of $\mathrm{N}$ - Kjeldahl). Based on these values, the $\mathrm{C}: \mathrm{N}$ ratio of coffee silverskin and expired coffee powder was quite similar and close to 20. The mineralization of organic nitrogen is favorable over its immobilization in this condition (CANTARELLA, 2007), making the agricultural use of such wastes promising.

In addition to this, either the organic carbon, the N-Kjeldahl of the material tested was in accordance with the organic wastes minimum content established by the Agriculture Ministry at Normative No. 25 of 2009 , which corresponds to $150 \mathrm{~g} \mathrm{~kg}^{-1}$ and $5 \mathrm{~g} \mathrm{~kg}^{-1}$ for $\mathrm{C}$ and $\mathrm{N}$, respectively.

The inorganic nitrogen, in the form of $\mathrm{NH}_{4}^{+}$ and $\mathrm{NO}_{3}^{-}+\mathrm{NO}_{2}^{-}$ions, was quite different among the wastes, being higher for the expired coffee powder than for coffee silverskin. However, for both wastes, the $\mathrm{NO}_{3}{ }^{-}$content was higher than $\mathrm{NH}_{4}^{+}$. This can be related to a high oxidation level of the materials since over time, a decrease in $\mathrm{NH}_{4}^{+}$and increase in $\mathrm{NO}_{3}^{-}$due to the bacterial nitrification are expected (SANCHÉZ-MONEDERO et al., 2001). The agricultural use of wastes with high amounts of $\mathrm{NO}_{3}^{-}$needs additional caution since $\mathrm{NO}_{3}^{-}$may be easily leached through the soil profile, causing environmental damage (MELO et al., 2008). Since more than $90 \%$ of the nitrogen in the wastes is in the organic form, even the nitrate content in the expired coffee powder was not troublesome. Furthermore, the nitrate can be retained by the positive charges due to the presence of $\mathrm{Fe}$ and $\mathrm{Al}$ oxides in the soil, principally in the deep layers (OLIVEIRA et al., 2000). The CEC, $354 \mathrm{mmol}_{\mathrm{c}} \mathrm{dm}^{-3}$ for expired coffee powder and $523 \mathrm{mmol}_{\mathrm{c}}^{\mathrm{c}} \mathrm{dm}^{-3}$ for coffee silverskin, was above the limit for soil conditioner set by Normative No. 35 (BRASIL, 2006). Considering the typical low organic matter levels of tropical soils (FONTANA et al., 2014), the addition of such wastes could significantly improve the fertility of these soils by means of nutrient retention. Aside from that, the humification degree of the coffee silverskin, based on the CEC/OC, was superior to that of the expired coffee powder. The humification degree also indicates the organic matter maturity, which reflects an increase of the material's nutrient retention capacity (MELO et al., 2008; PAIVA et al., 2013). However, further testing would be need to verify such material impact on soil CEC, for soil conditioning.
The electrical conductivity of the wastes was 4.9 and $7.5 \mathrm{dS} \mathrm{m}^{-1}$ for expired coffee powder and coffee silverskin, respectively. Electrical conductivities in the range from 0.64 to $6.85 \mathrm{dS}$ $\mathrm{m}^{-1}$ are commonly used in agriculture (MELO et al., 2008). Thus, the long-term usage of expired coffee powder grounds in agriculture may require soil solution monitoring in order to prevent salinize.

Overall, higher nutrient concentrations were found in coffee silverskin than in expired coffee powder. It is not clear if this difference may be due to the roasting of the coffee bean or if it is related to the coffee tissue's physiology. It is known, however, that the coffee plant demands high potassium fertilization in leaves, comparable to that of nitrogen (MARTINEZ et al., 2014). This was indeed reflected in the wastes composition, with higher concentration in the coffee silverskin The presence of a considerable concentration of $\mathrm{K}$ in this waste makes its particularly interesting for tropical soils, which are poor in K, and many crops besides coffee itself, where some wastes are traditionally returned to the fields (LIMA, 2014; MOURA, 2016). The use of coffee silverskin or expired coffee powder as part of the potassium fertilization under those conditions might represent a significant advantage since $\mathrm{KCl}$ represents the major input of $\mathrm{K}$ for the crops (RODRIGUES et al., 2014). However, further testing would be need to verify this. Expired coffee powder also demonstrated considerable $\mathrm{S}$ presence. Sulfur in plants is related to protein synthesis, and it is absorbed in the form of sulfate released during organic matter mineralization (FIORINI et al., 2016; SOARES et al., 2017).

The micronutrients $\mathrm{Fe}$ and $\mathrm{Mn}$ were found in high concentration in both wastes. This can be attributed to the natural high concentration of such elements in Brazilian soils (BIONDI et al., 2011). Although coffee is not a molybdenum-demanding crop (MARTINEZ et al., 2014), a considerable concentration of molybdenum, higher than the required amounts of $\mathrm{B}, \mathrm{Cu}$ and $\mathrm{Zn}$, was found in the expired coffee powder.

The potentially toxic elements $(\mathrm{Pb}, \mathrm{Ni}$ and $\mathrm{Cd}$ ) were below the detection limits of the characterization method (Table 3 ). For both wastes, low to trace concentrations of selenium (12.4 \pm 0.73 and $5.5 \pm 0.37 \mathrm{mg} / \mathrm{kg}$ for coffee silverskin and expired coffee powder, respectively) and barium $(35.7 \pm 1.8$ and $14.0 \pm 01.6 \mathrm{mg} / \mathrm{kg}$ for coffee silverskin and coffee silverskin respectively) were found. Only coffee silverskin contained some arsenic $(5.0 \pm 0.4 \mathrm{mg} / \mathrm{kg})$ and chromium $(1.7$ $\pm 0.4 \mathrm{mg} / \mathrm{kg}$ ). These results are well below those allowed by Normative No. 7 (BRASIL, 2016). 
The maize grown in soil treated with the coffee organic wastes, did not differ from that of the control $(p<0.05)$. For all treatments, plants were shorter than those grown in soil treated with ammonium nitrate, where all the nitrogen added in the inorganic form was available to plants (Figure 1). This behavior may indicate that the nitrogen mineralized from coffee silverskin and expired coffee powder was not reflected in plant growth, or if nitrogen mineralization occurred, the presence of another toxic substance (such as tannins) inhibited plant growth. Since chlorosis symptoms were observed, nitrogen deficiency seems to explain the plants' inferior development (COSTA et al., 2015).

After 52 days of the addition of the coffee organic wastes to the soil (15 days of incubation plus 37 days after maize sowing), the shoot nitrogen content and nitrogen extraction per pot did not differ for treatments that received the coffee organic wastes and the control (Table 4). As observed for the plants height, shoot dry matter weight did not differ. Once more, both the control and treatments with coffee wastes applied differed significantly from the mineral reference treatment. This trend was also reflected by the AEI and RAEI of coffee silverskin and the expired coffee powder when compared to the ammonium nitrate treatment $(\mathrm{p} \leq 0.05)$. Considering the costs involved in the high waste volumes needed to be applied in the field and its low nutrient availability, AEI values lower than $60 \%$ are considered low and not economically valuable.

TABLE 3 - Potentially toxic elements from the organic wastes.

\begin{tabular}{|c|c|c|c|c|c|c|c|}
\hline \multirow{2}{*}{ Organic waste ${ }^{a}$} & $\mathrm{~Pb}$ & $\mathrm{Ni}$ & $\mathrm{Se}$ & As & $\mathrm{Cd}$ & $\mathrm{Cr}$ & $\mathrm{Ba}$ \\
\hline & \multicolumn{7}{|c|}{$\mathrm{mg} \mathrm{kg}^{-1}$} \\
\hline Coffee silverskin & $<3.0^{\mathrm{b}}$ & $<2.4$ & $\begin{array}{c}12.4 \pm \\
0.73\end{array}$ & $\begin{array}{c}5.0 \pm \\
0.87\end{array}$ & $<0.4$ & $\begin{array}{l}1.7 \pm \\
0.25\end{array}$ & $\begin{array}{c}35.7 \pm \\
1.79\end{array}$ \\
\hline Expired coffee powder & $<3.0$ & $<2.4$ & $\begin{array}{c}5.5 \pm \\
0.37\end{array}$ & 0.0 & $<0.4$ & $<0.3$ & $14.0 \pm 1.6$ \\
\hline Normative No. 7 & 150 & 70 & 80 & 20 & 3 & 200 & $\mathrm{ni}^{\mathrm{c}}$ \\
\hline
\end{tabular}

$\mathrm{a}=$ Average and standard deviation for three replicates, $\mathrm{b}=$ lower than the quantification limit, $\mathrm{c}=$ no informed

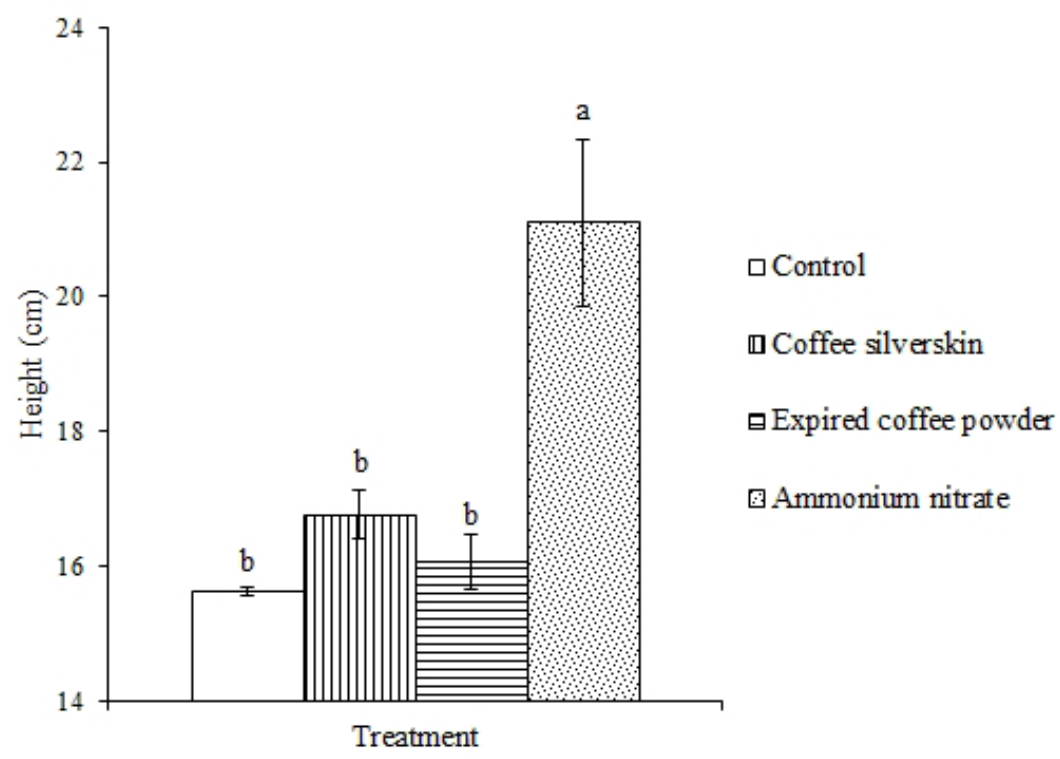

FIGURE 1 - Average height of maize plants in soil treated with coffee organic wastes, and controls. Columns with the same letters do not differ significantly by Tukey test $(p<0.05)$. 
TABLE 4 - Nitrogen absorption and efficiency index of nitrogen for maize.

\begin{tabular}{cccccc}
\hline \multirow{2}{*}{ Treatment } & Dry matter weight & $\begin{array}{c}\text { N Kjeldahl } \\
\text { content }\end{array}$ & $\begin{array}{c}\text { Shoot nitrogen } \\
\text { extraction }\end{array}$ & AEI & RAEI \\
\cline { 2 - 6 } & $\mathrm{g}$ & $\mathrm{g} \mathrm{kg}^{-1}$ & $\mathrm{mg} \mathrm{pot}^{-1}$ & \multicolumn{2}{c}{$\%$} \\
\hline Ammonium nitrate & $41.95 \mathrm{a}$ & $13.13 \mathrm{a}$ & $550.8 \mathrm{a}$ & $92.4 \mathrm{a}$ & $100.0 \mathrm{a}$ \\
Coffee silverskin & $23.72 \mathrm{~b}$ & $7.14 \mathrm{~b}$ & $169.4 \mathrm{~b}$ & $7.9 \mathrm{~b}$ & $8.5 \mathrm{~b}$ \\
Expired coffee powder & $20.7 \mathrm{bc}$ & $7.67 \mathrm{~b}$ & $158.8 \mathrm{bc}$ & $5.5 \mathrm{~b}$ & $6.0 \mathrm{~b}$ \\
Control & $18.7 \mathrm{c}$ & $7.16 \mathrm{~b}$ & $133.9 \mathrm{c}$ & - & - \\
\hline
\end{tabular}

Different letters indicate a significant difference between treatments at the $5 \%(\mathrm{P}<0.05)$ level by Tukey's test. AEI $=$ agronomic efficiency index, $\mathrm{RAEI}=$ relative agronomic efficiency index

The low nitrogen availability, despite a favorable $\mathrm{C}: \mathrm{N}$ ratio in coffee silverskin and expired coffee powder, may be due to the organic composition of the wastes associated with the presence of recalcitrant organic compounds, such as cellulose and hemicellulose (SANTOS et al., 2012). Mussato et al. (2011) reported that the presence of fibrous tissues in coffee silverskin was associated with those compounds. Lignin is also related due the high stability of vegetable tissues (BRUM, 2007).

In addition to recalcitrant compounds, the limited nitrogen availability of coffee silverskin and expired coffee powder may be related to the presence of caffeine, tannins and polyphenols. These compounds are toxic to microorganisms and may avoid organic matter mineralization (MUSSATTO et al., 2011; HERMOSA, 2014). Inhibition of extracellular enzymes and direct action on microbial metabolism are some mechanisms of microorganism inhibition due to the presence of tannin (SCALBERT, 1991). Besides that, a protein-tannin complex may be formed in the soil (KRAUS, 2003), that are resistant to $\mathrm{N}$ release (HOWARD; HOWARD, 1993).

In addition to this, caffeine and polyphenols are allelopathic to several vegetable species (LIMA et al., 2014). Chandra et al. (2013) found allelopathic activity against Cicer arietinum and Triticum aestivum caused by coffee bean extract, with a significant reduction of germination for both species.

\section{CONCLUSIONS}

Although coffee silverskin and expired coffee powder showed nitrogen levels were well above the minimum require by regulation $(0.5 \%$ $\mathrm{m} / \mathrm{m}$ ), its use as organic fertilizers (as exclusive sources of nitrogen) is not recommended since less than $10 \%$ of nitrogen was available as showed by the AEI index.

The use of these wastes as soil conditioners is promising due to their high organic matter content and CEC. In addition, these wastes may be used as complimentary sources of potassium. However, further testing is needed to confirm this

\section{ACKNOWLEDGEMENT}

This study was financed in part by the Coordenação de Aperfeiçoamento de Pessoal de Nível Superior-Brasil (CAPES) - Finance Code 001.

\section{REFERENCES}

AMERICAN PUBLIC HEALTH ASSOCIATION (APHA). Standard Methods for the Examination of Water and Wastewater, 23rd Edn. Washington, DC: American Public Health Association, 2017.

BIONDI, C. M.; NASCIMENTO, C. W. A.; NETA, A. B. F.; RIBEIRO, M. R. Teores de Fe, Mn, Cu, e Co em solos de referência de Pernambuco. Revista Brasileira de Ciência do Solo, Viçosa, v. 35, n. 3, p. 1057-1066, Nov. 2011.

BRASIL. Ministério da Agricultura, Pecuária e Abastecimento. Aprova os Métodos Analíticos Oficiais para Análise de Substratos e Condicionadores de Solos, na forma do Anexo à presente Instrução Normativa. Instrução Normativa n.17, de 21 de maio de 2007. 
BRASIL. Ministério da Agricultura, Pecuária e Abastecimento. Aprovar as normas sobre as especificações e as garantias, as tolerâncias, o registro, a embalagem e a rotulagem dos fertilizantes orgânicos simples, mistos, compostos, organominerais e biofertilizantes. destinados à agricultura, na forma dos Anexos à presente Instrução Normativa, n. 25, July 23, 2009.

BRASIL. Ministério da Agricultura, Pecuária e Abastecimento. Dispõe sobre as concentrações máximas admitidas para agentes fitotóxicos, patogênicos ao homem, animais e plantas, metais pesados tóxicos, pragas e ervas daninhas em fertilizantes, corretivos, inoculantes e biofertilizantes. Instrução Normativa n.7, May 02, 2016.

BRASIL. Ministério da Agricultura, Pecuária e Abastecimento. Fica aprovada as normas sobre especificações e garantias, tolerâncias, registro, embalagem e rotulagem dos corretivos de acidez, de alcalinidade e de sodicidade e dos condicionadores de solo, destinados à agricultura, na forma do Anexo a esta Instrução Normativa. Instrução Normativa n. 35, July $12,2006$.

BREMNER, J. M. Nitrogen total: In: SPARKS, D. L.; PAGE, A. L.; HELMKE, P. A.; LOEPPERT, R. H.; SOLTANPOUR, P. N.; TABATAI, M. A.; JOHNSTON, C. T.; SUMNER, M. E., eds. Methods of analysis. Part 3. Chemical methods. Madison, WI, Soil Science Society of America, 1996. p. 1085-1121.

BRUM, S. S. Caracterização e modificação química de resíduos sólidos do beneficiamento do café para produções de novos materiais. 2007. 152f. Dissertação (Mestre em Agroquímica) - Universidade Federal de Lavras, Lavras, 2007.

CANTARELLA, H. Nitrogênio. In: NOVAIS, R. F.; ALVAREZ, V. H. V.; BARROS, N. F.; FONTES, R. L. F.; CENTARUTTI, R. B.; NEVES, J. C. L, eds. Fertilidade do solo. Viçosa:Sociedade Brasileira de Ciência do Solo, 2007. p. 375-470.

CHANDRA, S.; DEY, P.; CHATTERJEE, P.; BHATTACHARYA, S. Allelopathic activity of coffee against Cicer arietinum and Triticum aestivum. Advances in Biogical Research, v. 7, n. 4, p. 129-133, Apr. 2013.

CONAMA (2006). Conselho Nacional do Meio Ambiente. Definir critérios e procedimentos, para o uso agrícola de lodos de esgoto gerados em estações de tratamento de esgoto sanitário e seus produtos derivados, e dar outras providências. n. ${ }^{\circ} 375$, Aug. 29, 2006.
CONCEIÇÃO, J. C. P. R.; JUNIOR, R. G. E.; CONCEIÇÃO, P. H. Z. Cadeia agroindustrial do café no Brasil: Uma análise do período recente. Radar, n. 53, 2017. Available: <http://repositorio.ipea.gov. br/bitstream/11058/8105/1/Radar_n53_cadeia.pdf $>$. Accessed in: May 05, 2018.

COSTA, R. M. C.; FREIRE, J. L. O.; MACEDO, L. P. M.; SILVA, F. L. S.; BORGES, C. H. A. Manejo de culturas e equilíbrio trofobiótico no perímetro irrigado Cruzeta, RN. Agropecuária Cientifica no Semiárido, Campina Grande, v. 11, n. 4, p. 72-86, Dec. 2015.

ECKHARDT, D. P.; REDIN, M.; JACQUES, R. J. S.; LORENSINI, F.; SANTOS, M. L. D.; WEILER, D. A.; ANTONIOLLI, Z. I. Mineralization and efficiency index of nitrogen in cattle manure fertilizers in the soil. Ciência Rural, Santa Maria, v. 46, n. 3, p. 472-477, Mar. 2016.

EPA. SW-846 Test Method 3051A: Microwave Assisted Acid Digestion of Sediments, Sludges, Soils, and Oils. Available: <https://www.epa.gov/ hw-sw846/ sw-846-test-method-3051a-microwave-assisted-aciddigestionsediments-sludges-soils-and-oils $>$. Accessed in: Aug 20, 2018.

ESQUIVEL, P.; JIMÉNEZ, V. M. Functional properties of coffee and coffee by-products. Food Research International, Ontario, v. 46, p. 488-495, May 2011.

FARINELLI, R.; LEMOS, L. B. Produtividade, eficiência agronômica, características nutricionais e tecnológicas do feijão adubado com nitrogênio em plantio direto e convencional. Bragantia, Campinas, v. 69, n. 1, p. 165-172, Jan. 2010.

FIORINI, I. V. A.; PINHO, R. G. V.; PIRES, L. P. M.; SANTOS, A. O.; FIORINI, F. V. A.; CANCELLIER, L. L.; RESENDE, E. L. Avaliação de fontes de enxofre e das formas de micronutrientes revestindo o NPK na cultura do milho. Revista Brasileira de Milho e Sorgo, Sete Lagoas, v. 15, n. 1, p. 20-29, Mar. 2016.

FONTANA, A.; PEREIRA, M. G.; ANJOS, L. H. C.; SANTOS, A. C.; BERNINI, T. A. Matéria orgânica de horizontes superficiais em topolitossequências em ambiente de Mar de Morros, Pinheiral, RJ. Revista Ciência Agronômica, Fortaleza, v. 45, n. 2, p. 221229, Apr./June 2014.

HERMOSA, V. A. B. Aproveitamento de resíduos do processamento semi-seco do café para a produção de compostos de valor agregado. 2014. 77f. Dissertação (Mestre em Microbiologia Agrícola) - Universidade Federal de Lavras, Lavras, 2014. 
HOWARD, P. J. A. HOWARD, D. M. 1993. Ammonification of complexes prepared from gelatin and aqueous extracts of leaves and freshly-fallen litter of trees on different soil types. Soil Biology \& Biochemistry, Leicestershire, v. 25, p. 1249-1256, Sept. 1993.

KRAUS, T. E. C.; DAHLGREN, R. A.; ZASOSKI, R. J. Tannins in nutriente dynamics of forest ecosystems a review. Plant and Soil, Perth. v. 256, n. 1,p. 41-66, Sept. 2003.

LIMA, L. K. S. Desenvolvimento do feijão caupi em função da utilização de resíduo da indústria do café como fonte de potássio. 2014. 81 p. Dissertação (Mestrado em Agronômia/Fitotecnia) - Universidade Federal do Ceará, Ceará, 2014.

LIMA, L. K. S.; SANTOS, C. C.; MOURA, M. C. F.; DUTRA, A. S.; FILHO, A. F. O. Utilização de resíduo oriundo da torrefação do café na agricultura em substituição a adubação convencional. Agropecuária Cientifica No Semiárido, Campina Grande, v. 10, n. 1, p. 14-19, Mar. 2014.

MARTINEZ, H. E. P.; CLEMENTE, J. M.; LACERDA, J. S. NEVES, Y. P.; PEDREOSA, A. W. Nutrição mineral do cafeeiro e qualidade da bebida. Revista Ceres, Viçosa, v. 61, n. 4, p. 838-848, Nov/Dec 2014.

MATIELLO, J. B. O café do cultivo ao consumo. São Paulo: Globo, 1991. p. 320

MELO, L. C. A.; SILVA, C. A.; DIAS, B. O. Caracterização da matriz orgânica de resíduos de origens diversificadas. Revista Brasileira de Ciência do Solo, Viçosa, Brasil, v. 32, n.1 , p. 101-110, Mar. 2008.

MOURA, M. C. F. Resíduos da torrefação do café como fonte de potássio no cultivo do Girassol. 2016. 79 p. Tese (Doutorado em Agronômia)-Universidade Federal do Ceará, Ceará, 2016.

MULVANEY, R. L. (1996), Nitrogen - Inorganic forms. In: Method of Soil Analysis: chemical methods. Part 3. D. L. Sparks. Madison: Soil Science Society of America, 1996, p. 1123-1184.

MUSSATO, S. I.; MACHADO, E. M. S.; MARTINS, S.; TEIXEIRA, J. A. Production, composition, and aplication os coffee and its industrial residues. Food bioproess tecnology, New York, v. 4, n. 5, p. 661-672, Mar. 2011.

NELSON, D. W.; SUMMERS, L. E. Methods of Soil Analysis. Part 3. Chemical Methods. Madison: Soil Science Society of America, n. 5, 1996, p. 961-1010.
OLIVEIRA, J. R. A.; VILELA, L.; AYARZA, M. A. Adsorção de nitrato em solos de cerrado do distrito federal. Pesquisa Agropecuária Brasileira, Brasilia, v. 35, n. 6, p. 1199-1205, June 2000.

PAIVA, E. C. R.; MATOS, A. T.; BARROS, R. T.; COSTA, T. D. R. Análise comparativa da adequação da relação $\mathrm{C} / \mathrm{N}$ e do índice $\mathrm{CT} / \mathrm{COT}$ como parâmetros da evolução da compostagem. In: CONGRESSO BRASILEIRO DE GESTÃO AMBIENTAL, 6., 2013, Salvador, Anais eletrônicos...Salvador: Instituto Brasileiro de Estudos Ambientais, 2013. Available: < http://www.ibeas.org.br/congresso/Trabalhos2013/II004.pdf>. Accessed in: Jan. 21, 2019

PAULA, J. R.; MATOS, A. T.; PEREIRA, M. S.; ANDRADE, C. A. Mineralização do carbono e nitrogênio de resíduos aplicados o solo em campo. Revista Brasileira de Ciência do Solo, Viçosa, v. 37, n. 6, p. 1729-1741, Nov./Dec. 2013.

RAIJ, B. VAN; ANDRADE, J.C.; CANTARELLA, H.; QUAGGIO, J.A. Análise química para avaliação de fertilidade de solos tropicais. Campinas: Instituto Agronômico de Campinas, 2001, 285p.

RODRIGUES, M. A.; BUZETTI, S.; FILHO, M. C. M. T.; GARCIA, C. M. P. ANDREOTTI, M. Adubação com $\mathrm{KCl}$ revestido na cultura do milho no Cerrado. Revista Brasileira de Engenharia Agrícola e Ambiental, Campina Grande, v. 18, n. 2, p. 127-133, 2014.

RONQUIM, C. C. Conceitos de fertilidade do solo e manejo adequado para as regiões tropicais, Campinas: Embrapa Monitoramento por Satélite, 2010. 30p. (Boletim de Pesquisa e Desenvolvimento, 8).

SANCHÉZ-MONEDERO, M. A.; ROIG, A.; CEGERRA, J.; BERNAL, M. P. Nitrogen transformation during organic waste composting by the Rutgers system and its effects on $\mathrm{pH}, \mathrm{EC}$ and maturity of the composting mixtures. Bioresource Technology, Lisbon, v. 78, n.3, p. 301-308, July 2001.

SANTOS, F. A.; QUIRÓZ, J. H.; COLODETTE, J. L.; FERNANDEZ, S. A.; GUIMARÃES, V. M.; REZENDE, S. T. Potencial da palha de cana-de-açúcar para produção de etanol. Química Nova, São Paulo, v. 35, n. 5, p. 1004-1010, Jan. 2012.

SCALBERT, A. Antimicrobial properties of tannins. Phytochemistry, Bari v. 30 , n. 12 p. 3875-3883, Dec. 1991.

SOARES, M. M.; BARDIVIESSO, D. M.; BARBOSA, W. F. S.; BARCELOS, M. N. Adubação de cobertura com enxofre na cultura da rúcula. Revista de Agricultura Neotropical, Cassilândia, v. 4, n. 1, p. 4952, Mar. 2017. 